\title{
Det populære
}

- Redaktionelt forord

På Kalundborgbådens agterdak. forefindes morskabsautomater et populart et populart et populart tidsfordriv

Sådan sang Steffen Brandt fra den århusianske popgruppe TV-2 i 1988 på nummeret "Kalundborgbåden" om de mennesker, der flokkedes om færgernes spillemaskiner i en kamp mod kedsomheden på de langsomme færgeoverfarter mellem Jylland og Sjælland. Brandt fangede øjeblikkets popularitet med sine morskabsautomater, der udfyldte en funktion for de rejsende, men som sat $\mathrm{i}$ en anden kontekst ville fremstå som knap så populære. At noget er populært er samtidig også afgrænsende og definerende i forhold til, hvordan vi som mennesker forholder os og opfører os på et givet tidspunkt i vores liv og i vores historie. Populærkulturen er med til at definere os som mennesker. Den fortæller historier om, hvem vi er og har været, på en måde der ikke bare reflekterer det omkringliggende samfund, men også bidrager med et originalt indhold. Samme overbevisning havde den Pulitzer-vindende, amerikanske tegner Jules Feiffer, da han i 1966 proklamerede:

You can always take the pulse of a time by studying its second-rate arts—its western and crime movies, radio and TV shows, its true love magazines, its comic books. They are all close approximations of the fantasy life of the lowest common denominator. [...] To know the true temper of a nation's people, turn not to its sociologists; turn to its junk. ${ }^{1}$ 
Det populære lader sig vanskeligt indfange i én alt omsiggribende definition. Den klassiske skelnen mellem finkultur og lavkultur er ofte blevet kritiseret inden for en række humanvidenskabelige fagområder og samtidig har forestillingen om, at idéer og viden bevæger sig ensidigt fra højere samfundslag ud til 'pøbelen' og 'masserne', lidt nederlag. Men hvordan skal man som humanistisk forsker forholde sig til de populære strømninger, og hvordan skal man tilgå emner, som stadigvæk anses for at ligge i yderkanten af videnskabernes respekterede områder. William Irwin skriver i sit bidrag til dette nummer af SLAGMARK:

Den sikreste måde at miste en komedie-fans opmærksomhed på, er ved at diskutere filosofi om komedie, og den sikreste vej til at miste offentlighedens opmærksomhed, er ved at tale om filosofi om populærkultur.

For forskere med interesse for det populære kan faldgruberne være mange og respekten fra det akademiske samfund være hårdt tilkæmpet. Denne udgave af SLAGMARK behandler Det Populære som forskningsfelt og viser, at populærkultur ikke bare er et spændende humanistisk forskningsfelt, men også et område med et stort erkendelsesmæssigt potentiale.

Temasektionen indledes af tre introducerende bidrag, der behandler spørgsmålet om, hvad det populære er, hvorfor og hvordan filosoffer, kulturog idéhistorikere skal beskæftige sig med det.

Carsten Fogh Nielsen åbner dette nummer af Slagmark med sin artikel "“Det er jo bare underholdning" - om filosofi, populærkultur og underholdning", der sætter fokus på filosofiens anspændte eller direkte fjendtlige forhold til populærkulturen. Denne modvilje er forfejlet og Carsten Fogh Nielsen argumenterer med udgangspunkt i en diskussion af begrebet underholdning og spørgsmålet om underholdningens normative status for, at filosofiske fordomme stiller sig i vejen for vigtige analyser udelukkende på baggrund af forestillingen om populærkulturen som værende mindre værdifuld.

William Irwin fortsætter diskussionen om filosofiens forbindelse til populærkulturen i sin artikel "Filosofi som/og/om populærkultur", hvor han undersøger, hvad populærkultur overhovedet kan siges at være. Herefter følger en redegørelse for forbindelsen mellem filosofi og populærkultur i USA. Den voksende bekymring blandt intellektuelle for populærkulturens korrumpering af det amerikanske samfund kan ikke accepteres som et tilstrækkeligt grundlag for at afvise populærkulturens tiltrækning af 
masserne som en potentiel fordel for filosofisk udfoldelse og uddannelse.

Louise Fabian gør også opmærksom på det problematiske og vanskeligt definerbare ved begrebet om det populære i sin artikel "Da Batman indtog elfenbenstårnet - Opgraderingen af populær- og hverdagskulturen som analyseobjekt". Med udgangspunkt i Cultural Studies leverer Fabian en idéhistorisk analyse af populærkulturens teorihistorie og viser, hvordan studiet af populærkulturen indenfor cultural studies placerer sig i et metodisk krydsfelt. Artiklen viser, hvordan bl.a. kreativ hverdagspraksis blandt subkulturer, forhandlinger af magtrelationer, kontekstuel betydningsdannelse og forholdet mellem det lokale og det globale er blevet anvendt som prismer for kritiske analyser indenfor cultural studies.

Efter de tre introducerende artikler følges der op med fire artikler, der eksemplificerer, hvordan man kan beskæftige sig filosofisk, historisk eller samfundsanalytisk med et populærkulturelt felt.

Christian Olaf Christiansen undersøger i "Livsmanualernes popularitet - hvorfor Covey's vaneparadigme blev populært i 1990'erne”, hvorfor Stephen Covey's paradigme om de syv gode vaner blev en af 1990'ernes mest populære ledelses- og selvudviklingsteorier. Covey's teori adskilte sig fra andre samtidige ledelseskoncepter blandt andet ved at kombinere erhvervslitteratur med populær selvhjælpslitteratur, men fokuserede samtidig på vane- og karakterbegreber og tilføjede dermed en specifik praktisk dimension.

Kristian Hvidtfelt Nielsen og Laura Søvsø Thomasen beskriver i "Smilla, Anna og Alexandra: Videnskabskvinder i nyere dansk populærlitteratur", hvordan tre videnskabskvinder portrætteres i populærlitteraturen. Artiklen rejser spørgsmålet om, hvordan kvindeligheden påvirker fremstillingen af forskerrollen, og hvilke litterære forskelle der er i forhold til populærvidenskabelige fremstillinger af videnskabsmænd. De tre kvindelige romanfigurer analyseres i forhold til tre analytiske niveauer, hvorigennem naturvidenskab har vekselvirket med skønlitteratur i det 20. århundrede; et offentligt, et videnskabeligt og et æstetisk niveau.

Fra litteraturen bevæger SLAGMARKs temanummer om det populære sig over i filmens verden med temasektionens tre sidste artikler. Først analyserer Lone Koefoed Hansen og Christopher Gad filmen "Minority Report i artiklen Præventive potentialer - populærkulturens overvejelser om overvågning”. Artiklen giver et eksempel på, hvordan populærkultur kan være et frugtbart område for humanvidenskabelig forskning og bruger filmens indhold til at forstå og nuancere overvågningsteknologier- 
nes præventive potentialer. Her kommer forholdet mellem menneske og teknologi i spil og filmens budskab perspektiveres til aktuelle forskningsprojekter i nutidens Belfast.

Kristoffer Hegnsvad tager også afsæt i filmens verden og tildelingen af De gyldne palmer til Michael Moores Fabrenheit 9/11 i sin artikel "Et forsvar for populærkulturen - en præcisering af det populærkulturelle begreb og en kritisk læsning af Adornos syn på populærkulturen”. Artiklen giver et filosofisk bud på populærkulturens kamp for anerkendelse og en kritisk analyse af Adornos tekststykker Om kulturindustrien og On Popular Music.

Dette nummers temasektion afsluttes af Carsten Bagge Laustsens artikel "Film og samfund". Der er her tale om en længere redegørelse for samfundsvidenskabernes forhold til film og filmens relevans for samfundsvidenskaberne. Forholdet mellem filmens og virkelighedens verden analyseres gennem filmene Being there og Storytelling, hvor tre læsninger præsenteres; det filmiske samfund, sociofiktionen og endelig film som tvetydige kulturelle produkter, der er objekter for en kamp om betydning.

Intermezzo består i denne udgave af SLAGMARK af Søren Harnow Klausens "Erkendelsens former". Artiklen er en revideret udgave af den tiltrædelsesforelæsning, som han gav, da han tiltrådte sin stilling som professor i filosofi ved Syddansk Universitet i 2008. Artiklen undersøger de måder, hvorpå man kan identificere forskellige typer af viden af praktisk relevans, og sætter fokus på de nuværende utilstrækkelige distinktioner, der eksisterer indenfor området.

Som altid afsluttes SLAGMARK af en fyldig sektion med anmeldelser, hvor vi tager pulsen på aktuel litteratur.

\section{Noter}

${ }^{1}$ Citatet er hentet fra udstillingen Blurring the Lines, Library of Congress, Washington, DC. 